Apidologie, 1987, 18 (4), 293-304

\title{
OVERWINTERING PERFORMANCE OF HONEY BEE COLONIES HEAVILY INFESTED WITH ACARAPIS WOODI (RENNIE)
}

\author{
Frank A. EISCHEN \\ Department of Entomology, University of Georgia, Athens, Georgia 30602
}

\begin{abstract}
SUMMARY
Three groups of honey bee colonies $(\mathrm{N}=30$ ) were overwintered on a mountainside $(2800 \mathrm{M})$ in northeastern Mexico. Infestation levels of Acarapis woodi in the three groups averaged $0,28.2$ and $86.0 \%$ for the control, moderately, and heavily infested colonies, respectively. Heavily infested colonies were $28 \%$ smaller than controls $(\mathrm{P}<0.01)$ in the fall. Adjusting for this, heavily infested colonies lost significantly more bees than either the moderately infested group, or the controls $(\mathrm{P}<0.0001)$. Both the moderately and heavily infested groups of bees had less brood than controls at the end of the test $(P<0.02$ and $P<0.01$ respectively). Similarly, honey consumption was higher in the heavily infested group $(P<0.04)$. Infestation levels were negatively correlated with colony size at the beginning of the test $(P<0.05)$ and at its end $(P<0.001)$.
\end{abstract}

\section{INTRODUCTION}

The recent introduction of the honey bee tracheal mite (Acarapis woodi) into the United States has created concern and uncertainty in the American apicultural community. This stems largely from the fact that assessments of this parasite's importance differ sharply (ADAM, 1950, 1968, 1983, 1985 ; BAILEY, 1961, 1964, 1968, 1985 ; GioRdanI, 1965 ; GiaVARINI and GioRdANI, unpublished ; Morgenthaler, 1929, 1930, 1964 ; RenNie et al., 1921 ; ReNnie, 1923 ; see also Crane, 1953 and Willie, 1966).

Briefly, adult female mites enter the prothoracic tracheae of young adult honey bees, puncture the tracheal walls and suck hemolymph. The life cycle including mating is completed in the trachea. Damage to the bee may be in the form of : 1) reduced air flow due to blockage by mites and debris (particularly of the smaller branching tracheae, Morison, 1927 ; ANDERSON, 1928) 2) nutrient loss due to hemolymph feeding (thought to be a minor cause of damage by a number of investigators) 3) puncture wounds allowing secondary infections (FeKL, 1956 ; but see BAILEY, 1965), 4) injury to muscle and nerve tissue near tracheae (WHITE, 1921 ; ANDERSON, 1928), damage to wing 
muscles due to external wing base feeding during winter (SCHNEIDER, 1941), 5) altered or restive behavior due to irritability produced by mite movement and feeding (Prell, 1927; Morgenthaler, 1944), 6) mite toxin causing flight muscle paralysis (KILlICK, 1923), 7) altered metabolism (SKROBAL, 1965), 8) interference of flight muscles due to stiffened trachea (Prell, 1927), 9) shortened longevity (BAILEY, 1958 ; BaILEY and LeE, 1959 ; GroRdanI, 1965). In extreme situations, populations in the prothoracic tracheae exceed 100 mites per bee (Morison, 1931 ; EISCHEN, unpublished).

In our surveys of northeastern Mexico (States of Nuevo Leon and Tamaulipas) we found that during the late winters of 1985 and 1986 the prevalence (c) of colony infestation was $61 \%$ and $70 \%$, respectively (WILSON et al., unpublished, EISCHEN, unpublished, see also Guzman-Nova and ZozAYA-RuBio, 1984). In 1985, $35 \%$ of the colonies had infestations in which greater than $30 \%$ of the workers were infested. Heavy infestations (>30\%) were observed in $45 \%$ of the colonies sampled in 1986. BAILEY $(1958,1961)$ reported that when infestations reached the $30 \%$ level, colonies were more likely to have difficulties overwintering. This may be especially true in those areas that have long winters. Certainly, this must be the time of greatest stress as most colony mortality occurs during this time (SEELEY, 1978, 1983). If $A$. woodi causes an adverse effect on bees, then it follows that this effect should be most easily detected during winter. This report presents the results of an experiment designed to assess the overwintering ability of infested honey bee colonies.

\section{MATERIALS AND METHODS}

Current parasitological terminology does not cover social organisms (Margous et al., 1982; G.W. EscH, personal communication). To insure clarity the following three terms are used in this paper : 1) prevalence (c), the percentage of colonies found infested in a given area ; 2) prevalence (w), the percentage of workers found infested within a single colony ; 3) parasite load, the number of mites found within an individual bee. When discussing infestations in non-quantitative ways other descriptive terms are occasionally used.

Prior to testing, colonies were located near San Rafael, Nuevo Leon, Mexico (lat. $25^{\circ} 02^{\prime} \mathrm{N}$ long. $100^{\circ} 33^{\prime} \mathrm{W}$ lat. el. $1900 \mathrm{~m}$ ), and had been managed for honey production. On November 16, 1985 samples of 20 bees were removed from the cover of the colonies and examined for their degree of infestation. Three groups of 30 colonies each were designated, i.e. uninfested $[0.0 \%$ prevalence $(w)]$, moderately $(10-50 \%)$, and heavily infested $(70-100 \%)$. Colony population and food reserves were assessed during late November. Estimates were made in tenths of frame equivalents (standard Langstroth). Examinations were made blind, i.e. without knowing the group designation. Colonies within each group were then randomly assigned to either a unmedicated or medicated subgroup. Medicated colonies received four grams of Fumidil-B ${ }^{R}$ (fumagillin) dissolved in two liters of $60 \%$ sucrose syrup ( $\mathrm{vol} / \mathrm{vol}$ ). They also received ca. $7 \mathrm{~g}$ of Terramycin-25 $5^{\mathrm{R}}$ (oxytetracycline) dispersed in $27 \mathrm{~g}$ of powdered sugar. Controls received sucrose syrup only. Additionally, a few colonies received 1-2 frames of sealed honey to insure sufficient stores for overwintering. 
Colonies were then transported to Cerro El Potosi, N.L. (lat. $24^{\circ} 53^{\prime} \mathrm{N}$ long. $100^{\circ} 13^{\prime} \mathrm{W}$, el. $2800 \mathrm{~m}$ ) on December 3, 1985. Colonies were placed on the northeastern face of the mountain and situated so that during the afternoon they were in its shadow about $2.5 \mathrm{~h}$. before sunset. They were grouped according to infestation level, with the heavily infested colonies separated from the others by ca. $50 \mathrm{~m}$. Intercolony distance was about $1 \mathrm{~m}$. A hygrothermograph was placed in an empty hive near the most heavily infested group. Climatic data collection on C. El Potosi was interrupted during Dec. 14-Feb. 5. However, a continuous recording was taken at Galeana N.L. about $20 \mathrm{~km}$ distant. The difference in temperatures between the two sites was relatively constant, and allowed an estimate of January temperatures on C. El Potosi. Conditions on the mountain were casually inspected on 12 occasions during the 90 day test. Additionally, samples of 20 bees/colony were examined for mites on Dec. 11 , Feb. 5, and Mar. 3. These examinations were made blind.

Dissections were performed after the methods described by EISCHEN et al. (1986), with the following modifications. Both prothoracic tracheae were detached at the bifurcations leading to the head and air sacs. While still attached at the spiracle, each trachea was draped over the notum and then examined for mites. This procedure minimizes disturbance to the tracheae, allows a reasonably clear view of its interior, and is relatively easy to perform. An estimate of the parasite load (eggs, larvae, and adults) was made on the February samples. Each trachea was given a numerical score reflecting the number of mites, viz, 0 (uninfested), $1(\leq 10), 2(>10 \leq 20), 3(>20 \leq 30)$, or $4(>30)$. Colony totals using 20 bee samples could range from $0-160$.

During February 20-23 colony populations and food reserves were reassessed. Though colony grouping was known, during the examination, the colony's status 82 days previous was not. An analysis of covariance was used to evaluate the difference between these two assessments. The analysis assumed that rates of change for the three groups were not equal, and mean differences were tested for significance (SNEDECOR and Cochran, 1967). Aresine transformed data were used to calculate t-statistics.

\section{RESULTS}

Temperatures at the test site averaged $7.1,5.2$ and $8.9^{\circ} \mathrm{C}$ for the months of December, January, and February, respectively (Table 1). Daytime temperatures were often high enough to allow cleansing flights. Relative humidity during December and February averaged 71.8 and $52.0 \%$ respectively. Clouds of moist air occasionally encircled the mountain creating fog conditions. A snow cap formed and reached to within ca. $500 \mathrm{~m}$ (elevation) of the colonies. During inspection visits, strong gusts of cold wind occurred. By northern United States standards, the winter on C. El Potosi was relatively mild. Temperatures were similar to those recorded for northern Georgia and central Tennessee (Anon. 1980). During the late winter examination, two colonies in Group I (uninfested) and three in Group II (moderately infested) were found queenless. One colony in Group III (heavily infested) had died.

At the beginning of the test (Nov. '85) prevalence (w) averaged 0, 28.2, and $86.0 \%$ for Groups I, II, and III, respectively (Table 2). In general, prevalence $(w)$ rose as the winter progressed. By February, mites were found in $40 \%$ of the « uninfested " colonies of Group I. Infestations were light and $5 \%$ or fewer of the bees were parasitized. No significant differences were found for prevalence $(w)$ between unmedicated (control) and medicated sub- 
TABL. 1. - Climatic conditions near overwintering colonies on Cerro El Potosi

\begin{tabular}{|c|c|c|c|}
\hline & $\begin{array}{l}\text { C. El Potosi } \\
\left({ }^{\circ} \mathrm{C}\right)\end{array}$ & $\begin{array}{l}\text { Galeana } \\
\left({ }^{\circ} \mathrm{C}\right)\end{array}$ & $\begin{array}{l}\text { C. El Potosi } \\
\text { R.H. }\end{array}$ \\
\hline \multicolumn{4}{|l|}{ December } \\
\hline $\begin{array}{l}\text { MIN }(X \pm S E) \\
\text { MAX }(X \pm S E) \\
\text { AVE }(X \pm S E)^{1}\end{array}$ & $\begin{array}{r}3.5 \pm 0.7 \\
10.6 \pm 0.5 \\
7.1 \pm 0.8\end{array}$ & $\begin{array}{r}5.1 \pm 1.3 \\
23.2 \pm 0.8 \\
14.2 \pm 1.9\end{array}$ & $\begin{array}{l}59.9 \pm 5.8 \\
83.7 \pm 4.2 \\
71.8 \pm 4.2\end{array}$ \\
\hline \multicolumn{4}{|l|}{ January } \\
\hline $\begin{array}{l}\text { MIN }(X \pm S E) \\
\text { MAX }(X \pm S E) \\
\text { AVE }(X \pm S E)\end{array}$ & $\begin{array}{l}(0.1)^{2} \\
(8.9) \\
(5.2)\end{array}$ & $\begin{array}{r}2.1 \pm 0.5 \\
21.5 \pm 0.7 \\
11.8 \pm 0.4\end{array}$ & $\begin{array}{l}- \\
-\end{array}$ \\
\hline \multicolumn{4}{|l|}{ February } \\
\hline $\begin{array}{l}\text { MIN }(X \pm S E) \\
\text { MAX }(X \pm S E) \\
\text { AVE }(X \pm S E)\end{array}$ & $\begin{array}{r}3.7 \pm 0.5 \\
13.4 \pm 0.8 \\
8.9 \pm 0.8\end{array}$ & $\begin{array}{r}6.1 \pm 0.7 \\
24.1 \pm 1.1 \\
15.1 \pm 1.3\end{array}$ & $\begin{array}{l}40.7 \pm 3.6 \\
63.3 \pm 4.3 \\
52.0 \pm 3.2\end{array}$ \\
\hline
\end{tabular}

I Average temperatures were calculated using minimum and maximum temperatures only.

2 January temperatures on $\mathrm{C}$. El Potosi were estimated by subtracting the average difference in temperatures at C. El Potosi and Galeana during Dec. and Feb. from the January Galeana temperature. Galeana $(20 \mathrm{~km}$ distant) was consistently warmer than the apiary site.

TABL. 2. - Acarapis woodi prevalence (w) in colonies of overwintering honey bees on Cerro El Potosi ${ }^{1}$

\begin{tabular}{l|c|c|c|c|c}
\hline \hline \multicolumn{1}{c|}{ Group } & $\mathrm{N}$ & $\begin{array}{c}\text { Nov '85 } \\
(\mathrm{X} \pm \mathrm{SE})\end{array}$ & $\begin{array}{c}\text { Dec '85 } \\
(\mathrm{X} \pm \mathrm{SE})\end{array}$ & $\begin{array}{c}\text { Feb '86 } \\
(\mathrm{X} \pm \mathrm{SE})\end{array}$ & $\begin{array}{c}\text { Mar '86 } \\
(\mathrm{X} \pm \mathrm{SE})\end{array}$ \\
\hline I Uninfested & & & & & \\
$\quad \begin{array}{c}\text { Control } \\
\text { Medicated }\end{array}$ & 15 & 0 & $2.7 \pm 1.2$ & $2.0 \pm 0.7$ & $-{ }^{3}$ \\
$\quad$ Average & 15 & 0 & 0 & $2.0 \pm 0.7$ & - \\
II Moderately Infested & & 0 & $1.3 \pm 0.6$ & $2.0 \pm 0.5$ & - \\
$\quad$ Control & 15 & $28.0 \pm 2.8^{4}$ & $27.3 \pm 4.7$ & $41.7 \pm 6.5$ & $49.6 \pm 6.0^{5}$ \\
$\quad \begin{array}{l}\text { Medicated } \\
\text { Average }\end{array}$ & 15 & $28.3 \pm 3.6$ & $25.6 \pm 3.7$ & $29.0 \pm 5.6$ & $30.0 \pm 7.3$ \\
III Heavily Infested & & $28.2 \pm 2.3$ & $26.4 \pm 2.9$ & $35.3 \pm 4.4$ & $39.8 \pm 5.0$ \\
$\quad$ & & & & \\
$\quad$ Control & 15 & $83.7 \pm 3.9$ & $80.7 \pm 4.9$ & $88.3 \pm 4.2$ & $90.6 \pm 3.1$ \\
$\quad \begin{array}{l}\text { Medicated } \\
\text { Average }\end{array}$ & 15 & $88.3 \pm 2.6$ & $88.7 \pm 2.0$ & $91.0 \pm 2.5$ & $83.0 \pm 3.6$ \\
& 30 & $86.0 \pm 2.3$ & $84.7 \pm 2.7$ & $89.7 \pm 2.4$ & $86.7 \pm 2.5$ \\
\hline
\end{tabular}

1 Prevalence $(w)$ was determined by examining 20 bees taken from the hive cover.

2 Medicated colonies received Fumidil- $B^{R}$ and Terramycin- $25^{R}$

3 Prevalence (w) was not determined in March, but was in April. It had risen slightly.

4 Prevalence $(w)$ in controls were significantly higher in Mar '86 than in Nov ' 85 for both Group II (paired $\mathrm{t}=4.43, \mathrm{P}<0.001$ ) and Group III (paired $\mathrm{t}=2.08, \mathrm{P}<0.05$ ).

Differences were not significant in the medicated colonies.

5 Prevalence $(w)$ in Group II controls was significantly higher than in the medicated group (unpaired $\mathbf{t}=2.13$, $P<0.01)$. This was not true in Group III. 
groups at the start of the test. However, when beginning infestations were compared with those at the end of the test, unmedicated colonies had a significantly higher prevalence $(w)$ for both Group II $(P<0.001)$ and Group III $(P<0.05)$. Differences in infestation at the beginning and end of the study in medicated colonies were not significant. Additionally, at the end of the test, unmedicated colonies in Group II had significantly higher prevalence $(w)$ than those that were medicated $(P<0.01)$. Infestations in individual colonies were variable, especially in the moderately infested group.

In December, the prevalence (w) of bilateral infestation (both prothoracic tracheae) averaged $0,5.2 \pm 1.4$, and $52.6 \pm 2.0 \%$ for Groups I, II, and III, respectively. The prevalence $(w)$ of bilateralism was positively correlated with the overall infestation level in both Group II $(\mathrm{r}=0.535, \mathrm{P}<0.01)$ and Group III $(\mathrm{r}=0.770, \mathrm{P}<0.001)$. Similar findings were made in February with the prevalence $(\mathrm{w})$ of bilateralism averaging $0,8.2 \pm 1.7$, and $66.3 \pm 4.6 \%$ for Groups I, II, and III, respectively. As in December, this type of infestation was positively correlated with the general level of parasitism in Group II $(\mathrm{r}=0.854, \mathrm{P}<0.001)$ and Group III $(\mathrm{r}=0.818, \mathrm{P}<0.001)$. Estimates of parasite loads in the February samples averaged $0.05 \pm 0.01,0.89 \pm 0.05$, and $3.91 \pm 0.11$ for Groups I, II, and III, respectively. Though it is not possible to translate these scores into exact mites/bee values, they represent about 0.4 , 6.8 , and $30 \mathrm{mites} /$ bee (prothoracic tracheal trunks only) for Groups I, II, and III, respectively. When these scores were used in lieu of infestation percentages for performing correlations with colony census values, the significance levels were raised. Presumably, more precise estimates of the parasite load would further improve correlations.

Table 3 shows population sizes and food reserves at the beginning (Nov. '85) and end of the test (Feb. '86). When initially examined, the heavily infested colonies were on average 1.6 frames of bees smaller, or about $72 \%$ as large as the controls $(P<0.01)$. No other significant differences were found among the brood, honey or pollen of the three groups. The heavily infested colonies lost on average $45.6 \%$ of their adult bee population, which was significantly greater $(\mathrm{P}<0.0001)$ than the control or the moderately infested colonies. These latter two groups (I and II) lost 11.6 and $20.0 \%$ respectively, of their starting populations. Brood populations were not significantly different among the three groups at the beginning of the test in November. By February, control populations had increased on average to $119.4 \%$ of their starting value. This quantity was significantly larger than the moderately infested group $(P<0.02)$ and the heavily infested group $(P<0.01)$.

Honey consumption was greatest for the heavily infested group and significantly different from the moderately infested $(P<0.04)$ and control colonies $(P<0.06)$. When colony size is taken into account, the rate of honey 
TABL. 3. - Estimates of colony populations and their resources while overwintering

\begin{tabular}{c|c|c|c|c|c}
\hline Group & $\begin{array}{c}\text { Nov 85 } \\
(\mathrm{X} \pm \mathrm{SE})\end{array}$ & $\begin{array}{c}\text { Feb '86 } \\
(\mathrm{X} \pm \mathrm{SE})\end{array}$ & $\begin{array}{c}\text { Difference } \\
(\mathrm{X} \pm \mathrm{SE})\end{array}$ & $\begin{array}{c}\text { Adjusted } \\
\text { Mean } \\
\text { Difference }\end{array}$ & $\begin{array}{c}\text { Feb./Nov. } \\
(\%)\end{array}$ \\
\hline Bees & & & & & \\
I & $5.7 \pm 0.4^{\mathrm{A}}$ & $5.0 \pm 0.3$ & $-0.7 \pm 0.2$ & $-0.47^{\mathrm{A}}$ & $-1.0 \pm 0.2$ \\
II & $5.1 \pm 0.3^{\mathrm{A}}$ & $4.1 \pm 0.3$ & $-0.97^{\mathrm{A}}$ & 88.4 \\
III & $4.1 \pm 0.3^{\mathrm{B}}$ & $2.2 \pm 0.3^{3}$ & $-1.9 \pm 0.2$ & $-2.39^{\mathrm{B}}$ & 54.4 \\
Brood & & & & & \\
II & $1.3 \pm 0.2$ & $1.5 \pm 0.2$ & $+0.2 \pm 0.2$ & $+0.16^{\mathrm{A}}$ & 119.4 \\
II & $1.4 \pm 0.2$ & $1.1 \pm 0.2$ & $-0.3 \pm 0.2$ & $-0.36^{\mathrm{B}}$ & 75.2 \\
III & $1.5 \pm 0.1$ & $1.0 \pm 0.1$ & $-0.5 \pm 0.2$ & $-0.40^{\mathrm{B}}$ & 66.7 \\
Honey & & & & & \\
I & $4.2 \pm 0.2$ & $2.4 \pm 0.04$ & $-1.8 \pm 0.1$ & $-1.83^{\mathrm{A}}$ & 57.3 \\
II & $4.3 \pm 0.3$ & $2.6 \pm 0.2$ & $-1.8 \pm 0.2$ & $-1.80^{\mathrm{A}}$ & 58.7 \\
III & $4.2 \pm 0.3$ & $2.2 \pm 0.2$ & $-2.1 \pm 0.1$ & $-2.17^{\mathrm{B}}$ & 50.8 \\
Pollen & & & & & \\
II & $0.8 \pm 0.1$ & $0.7 \pm 0.1$ & $-0.1 \pm 0.1$ & $-0.16^{\mathrm{A}}$ & 82.7 \\
II & $0.8 \pm 0.1$ & $0.6 \pm 0.2$ & $-0.2 \pm 0.1$ & $-0.23^{\mathrm{AB}}$ & 76.2 \\
III & $0.9 \pm 0.1$ & $0.5 \pm 0.1$ & $-0.4 \pm 0.1$ & $-0.39^{\mathrm{B}}$ & 52.3 \\
\hline
\end{tabular}

1 Test conducted at Cerro El Potosi ; Nuevo Leon, Mexico. Estimates made in tenths of standard Langstroth frames.

2 Average infestation for Groups I, II, III were $0 \%, 28.2 \pm 2.3$, and $86.0 \pm 2.3 \%$, respectively, at the beginning of the test.

$3 \mathrm{~N}=30$ for Groups I and II, N $=29$ for Group III as one colony died.

4 Means followed by the same letter are not significantly different, as determined by analysis of covariance.

consumption by the heavily infested colonies was about 1.5 times that of the moderately infested and control colonies. Pollen consumption values are difficult to interpret, as near the end of the test new pollen was collected. Some colonies had brought in considerable amounts, while others had collected none. Nevertheless, the heavily infested group had significantly less pollen than controls at the end of the test $(\mathrm{P}<0.03)$. The pollen reserves of the moderately infested colonies were intermediate and not significantly different from the other two groups. Medication with Terramycin ${ }^{R}$ and Fumidil- $B^{R}$ had no significant effect on brood populations or honey and pollen consumption. At the end of winter, however, medicated colonies in the moderately infested group had significantly more bees than the untreated colonies $(P<0.056)$.

Table 4 shows the correlation coefficients for colony census values and prevalence (w). No significant correlations were observed for the moderately infested colonies. Significant negative correlations were found between prevalence ( $w)$ and colony size of the heavily infested bees at the beginning $(P<0.05)$ and end of the test $(P<0.001)$. Similarly, the heavily infested colonies showed a significant negative correlation between prevalance $(w)$ and 
TABL. 4. - Correlation between Acarapis woodi prevalence (w) and quantities of bees, brood, and honey

\begin{tabular}{|c|c|c|c|}
\hline $\begin{array}{l}\% \text { infestation } \\
\text { correlated with : }\end{array}$ & Nov' 85 & Feb '86 & $\begin{array}{c}\text { Feb/Nov. } \\
\%\end{array}$ \\
\hline $\begin{array}{c}\text { Group II } \\
\text { Bees } \\
\text { Brood } \\
\text { Honey }\end{array}$ & $\begin{array}{l}-0.306^{2} \\
+0.152 \\
+0.194\end{array}$ & $\begin{array}{l}-0.170 \\
-0.101 \\
-0.105\end{array}$ & $\begin{array}{l}-0.314^{3} \\
+0.021 \\
-0.042\end{array}$ \\
\hline $\begin{array}{c}\text { Group III } \\
\text { Bees } \\
\text { Brood } \\
\text { Honey }\end{array}$ & $\begin{array}{l}-0.420^{*} \\
+0.074 \\
-0.463^{*}\end{array}$ & $\begin{array}{l}-0.650^{* * *} \\
-0.646^{* * *} \\
-0.300\end{array}$ & $\begin{array}{l}-0.514^{* *} \\
-0.412^{*} \\
-0.147\end{array}$ \\
\hline \multicolumn{4}{|c|}{$\begin{array}{l}1 \text { Group II, moderately infested: Group III, heavily infested. } \\
2 \text { November colony values correlated with November infestation levels, and similarly for February. All values } \\
\text { are correlation cofficients (r). } \\
3 \text { Percentages of bees, brood, and honey remaining at the end of the test are correlated with prevalence (w) at } \\
\text { the end of the test. } \\
{ }^{*} \mathrm{P}<0.05 ;{ }^{* *} \mathrm{P}<0.01 ;{ }^{* *} \mathrm{P}<0.001 \text {. }\end{array}$} \\
\hline
\end{tabular}

quantity of brood at the end of the test $(\mathrm{P}<0.001)$. The percentages of bees and brood observed at the end of the test were also negatively correlated with prevalence (w) $(P<0.01$ and $P<0.05)$, respectively. Prevalance $(w)$ was not significantly correlated with quantities of honey except at the beginning of the test $(\mathrm{P}<0.05)$.

\section{DISCUSSION}

The increased prevalence $(w)$ of $A$. woodi in overwintering unmedicated colonies has been observed previously (MORgenthaler, 1929, 1930 ; MORISON et al., 1956). The cause is thought to be linked to the decreasing bee populations concurrent with reduced brood production, both of which tend to increase the density of infested hosts (BAILEY and LEE, 1959). What has not been resolved is 1 ) whether mites continue to reproduce at their usual summer rates (see LAVIE, 1950 ; KAESER, 1952) ; and 2) whether young females invade and reproduce in old and normally resistant workers when failing to find their preferred young hosts (Giavarini and Giordani, unpublished). It is not known why infestations failed to increase in the medicated colonies. At the end of the test, the moderately infested bees had significantly more bees than the controls. Since brood quantity was not different, medicated bees may have lived longer. Alternatively, medications may have affected mite survival.

The loss of bees in the heavily infested colonies suggest that high populations of $A$. woodi are associated with the factor(s) causing these colonies to 
dwindle excessively. This is supported by the concurrent reduction of brood, honey and pollen. Additionally, the moderately infested colonies showed signs of being affected. They reared significantly less brood than uninfested controls. The negative correlations between mite levels and colony size (bees), also indicate an association between colony dwindling and $A$. woodi. A number of causes for dwindling have been suggested, though none proved. In this regard, GIORDANI $(1962,1965)$ found that infested bees had considerably shorter lifespans. However, BAILEY (1958) reported only a slightly shortened longevity. This issue might be resolved if the parasite load rather than prevalence (w) was monitored.

BAILEY (1961) and others have suggested that when mite levels exceed some threshold, there is an increased probability that the colony will have difficulty overwintering. Whether or not this occurs frequently enough to pose an economic threat is an unresolved issue. BaIley (1985) has argued that this does not occur in England. This is supported by census data currently showing relatively low levels of infestation. However, during the period 1925-1926, 55$65 \%$ of colonies in England were infested (Morison et al., 1956 ; BAILEY and Perry, 1982 ; BaIley, 1985). A gradual decline has occurred during the intervening years, and now infestations detectable with a 20 bee sample appear to vary between $1-10 \%$. Presumably, 60 years ago, not only were high percentages of colonies infested, but also many must have been heavily infested (i.e. $>30 \%$ see RENNIE et al., 1921). Why this decline has occurred is not clear. In any case, during the years following the discovery of $A$. woodi in England by RENNIE et al. (1921), a number of additional epidemics have been reported (see Crane, 1953 ; Giavarini and Giordani, unpublished; Gomez Pajuelo and Fernandez Arroyo, 1979 ; Kshirsagar, 1966 ; Smirnov, 1972). Abnormally high colony losses have apparently accompanied these outbreaks. In this study, it seems likely that had there been severe winter conditions, mortality of the heavily infested colonies would have been high.

In summary, no causality has been shown by this research. However, the data strongly suggest that there is an association between $A$. woodi infestation levels and colony health. This and the epidemic proportions of A. woodi in northeastern Mexico engenders concern for beekeeping in North America.

Received for publication in November 1986. Accepted for publication in August 1987.

\section{ACKNOWLEDGEMENTS}

A great many persons contributed to the completion of this work. Preston Hunter and Alfred Dietz of the Department of Entomology, University of Georgia provided encouragement and financial support. W.G. Hart, Manuel Sanchez, and W.T. Wilson of the USDA-ARS Subtropical Insects Lab. and 
Honey Bee Lab., respectively, supplied a vehicle and laboratory space. Danny Root and Alberto SuAREz of the U.S. Consulate, Matamoros and USDA-APHIS, respectively, helped in moving equipment and supplies across the international border. Rodolfo Garcia and Jorge Canru of Campo Agricola Experimental General Teran, INIA provided laboratory space and support while in Mexico. They were also very helpful, along with Julian MAROQUIN of SARH, in securing permission from the Mexican authorities for placing the bees on Cerro El Potosi. Discussions with Gerald Esch, Gard OTIS, and John Pickering helped clarify the parasitological terminology. Glenn WARE assisted with the statistics and Dorset HuRLEY provided expert technical assistance. My special thanks go to David CARDoso-TAMEZ and his family, who in addition to numerous hospitalities, supplied fruitful advice, the bees, and trucking. H. SHIMANuKI was instrumental in arranging financial support through Cooperative Agreement 25-21-RC293-098 with the Beneficial Insects Laboratory, PPI, USDA, Beltsville, Maryland.

\section{RÉSUMÉ \\ CAPACITÉS D'HIVERNAGE DE COLONIES D'ABEILLES DOMESTIQUES FORTEMENT INFESTEES PAR ACARAPIS WOODI (RENNIE)}

Cette recherche a été menée pour évaluer l'action des infestations par Acarapis woodi sur les colonies d'abeilles en hivernage. Le test a été réalisé à Cerro El Potosi (2 $800 \mathrm{~m})$, Nuevo Leon, au Mexique au cours de la période du 4 décembre 1985 au 3 mars 1986 (Tabl. 1). On a utilisé 3 groupes de colonies $(\mathrm{N}=30)$. Les taux d'infestation ( $w=\%$ d'abeilles infestées) ont été respectivement de $0 \%$, $28,2 \%$ et $86,0 \%$ pour les colonies témoins, modérément infestées et fortement infestées (Tabl. 2). Au début du test, les colonies fortement infestées étaient $28 \%$ plus faibles que les témoins $(\mathrm{P}<0,01)$. Fin février, ces colonies avaient perdu de façon significative plus d'abeilles que les deux autres groupes $(P<0,0001)$. De la même façon, les colonies modérément et fortement infestées avaient moins de couvain que les colonies témoins à la fin du test $(\mathrm{P}<0,002$ et $(\mathrm{P}<0,01)$ respectivement. Les colonies fortement infestées ont également consommé proportionnellement plus de miel $(P<0,04)($ Tabl. 3$)$.

Le taux d'infestation (w) d'A. woodi dans les colonies fortement infestées a été négativement corrélé avec la taille de la colonie, aussi bien au début $(P<0,05)$ qu'à la fin du test $(P<0,001)(T a b l .4)$. Dans ce même groupe la taille du nid à couvain a été aussi corrélée négativement avec le taux d'infestation (w) $(P<0,001)$. Le niveau significatif des corrélations s'est accru quand on a utilisé les estimations de la charge parasitaire au lieu du taux d'infestation (w). Le taux d'infestation (w) des infestations bilatérales a été respectivement d'environ $0 \%, 5,2 \%$ et $52,6 \%$ au début du test et de $0 \%, 0,2 \%$ et $66,3 \%$ à la fín du test pour les colonies témoins, modérément infestées et fortement infestées. Ce type d'infestation a été corrélé positivement avec le taux d'infestation (w) $(\mathrm{P}<0,001)$.

A l'automne on a administré à la moitié des colonies de chaque groupe de l'oxytétracycline et de la fumagilline. A la fin du test, les infestations dans les colonies modérément et fortement infestées ont été plus élevées que celles des colonies témoins au début du test : $\mathrm{P}<0,001$ et $\mathrm{P}<0,05$ respectivement. Les différences n'ont pas été significatives pour les colonies ayant reçu un traitement médicamenteux.

\section{ZUSAMMENFASSUNG}

\section{ÜBERWINTERUNGSLEISTUNG VON STARK MIT ACARAPIS WOODI (RENNIE) INFIZIERTEN HONIGBIENENVÖLKERN}

Diese Untersuchung sollte den Effekt einer Acarapis woodi Infektion auf die Überwinterungsleistung von Bienenvölkern bestimmen. Der Test wurde in Cerro El Potosi (2800 m), Nuevo Leon, Mexico, vom 4.12.1985 bis 3.3.1986 durchgeführt (Tab. 1). Drei Gruppen von Völkern $(\mathrm{n}=30)$ wurden benutzt : nicht, mittelmäßig und stark befallene Völker mit ciner Befallsrate ( $w=\%$ infizierter Bienen) von $0 \%$, $28.2 \%$ und $86.0 \%$ (Tab. 2). Die stark befallenen Völker waren zu Beginn des Tests um $28 \%$ 
schwächer als die nichtbefallenen Kontrollvölker $(p<0.01)$. Im späten Februar hatten diese Völker signifikant mehr Bienen verloren als die beiden anderen Gruppen ( $p<0.0001)$. Außerdem hatten dic mittelmäßig und die stark befallenen Kolonien weniger Brut als die Kontrollvölker am Ende des Tests $(p<0.02$ bzw. $p<0.01$ ). Die stark befallenen Völker konsumierten außerdem proportional mehr Honig $(\mathrm{p}<0.04)($ Tab. 3).

Die Befallsrate (w) von $A$. woodi in stark infizierten Kolonien war sowohl am Anfang wie am Ende des Test negativ korreliert mit der Volksstärke ( $p<0.05$ bzw. $p<0.001$ ) (Tab. 4). Auch die Größe des Brutnests war in dieser Gruppe negativ korreliert mit der Befallsrate $(w)(p<0.001)$. Das Signifikanzniveau der Korrelationen erhöhte sich, wenn eine Schätzung der parasitären Belastung anstelle der Befallsrate $(w)$ erfolgte. Die Befallsrate (w) bei bilateraler (beidseitiger) Infektion ergab durchschnittlich $0,5.2 \%$ und $52.6 \%$ zu Beginn des Tests und $0,8.2 \%$ und $66.3 \%$ am Ende des Test für die nicht, mittelmäßig und stark befallenen Völker. Dieser Typ der Infektion war positiv mit der Befallsrate (w) korreliert $(\mathrm{p}<0.001)$.

Die Hälfte der Kolonien aus jeder Gruppe wurde im Herbst medikamentös behandelt mit Oxytetracyclin und Fumagillin. Am Ende des Test war der Befall bei den nicht medikamentös behandelten Gruppen größer als zu Beginn in den Gruppen mit mittelmäßigem $(p<0.001)$ und mit starkem Befall $(p<0.05)$. Bei den medikamentös behandelten Völkern konnte kein signifikanter Unterschied festgestellt werden.

\section{REFERENCES}

AdAM B., 1950. - Beekeeping at Buckfast Abbey. Bee World, 31, 89-91.

ADAM B., 1968. - «Isle of Wight » or Acarine disease : its historical and practical aspects. Bee World, 49, 6-18.

ADAM B., 1983. - In search of the best strains of bees. Dadant \& Sons. Hamilton, Illinois, $206 \mathrm{p}$.

Adam B., 1985. - The Acarine disease menace- short-term and long-term counter measures. Am. Bee $J ., 125,163-164$.

ANDERSON E.J., 1928. - The pathological changes in honeybees infested with the Isle of Wight Disease. J. Econ. Entomol., 21, 404-408.

Anon., 1980. - Climates of the States. Vol. 2. Gale Research Co. Detroit, Michigan, 1185 p.

Balley L., 1958. - The epidemiology of the infestation of the honeybee, Apis mellifera L., by the mite Acarapis woodi (Rennie) and the mortality of infested bees. Parasitology, 48, 493-506.

BAlley L., 1961. - The natural incidence of Acarapis woodi (Rennie) and the winter mortality of honeybee colonies. Bee World, 42, 96-100.

Bailey L., 1964. - The «Isle of Wight disease »: the origin and significance of the myth. Bee World, 45, 32-37, 18.

Batley L., 1965. - Susceptibility of the honey bee, Apis mellifera Linnaeus, infested with Acarapis woodi (Rennie) to infection by airborne pathogens. J. Invertebr. Pathol., 7, 141-143.

Bailey L., 1968. - Honey bee pathology. Annu. Rev. Entomol, 13, 191-212.

Balley L., 1985. - Acarapis woodi : a modern appraisal. Bee World, 66, 99-104.

BAILEY L. and LEE D.C., 1959. - The effect of infestation with Acarapis woodi (Rennie) on the mortality of honcy bees. J. Insect. Pathol., 1, 15-24.

Bailey C. and J.N. Perry, 1982. - The diminished incidence of Acarapis woodi: (Rennie) (Acari : Tarsonemidae) in honeybees, Apis mellifera L. (Hymenoptera : Apidae) in Britain. Bull. Entomol. Res., 72, 655-662.

Crane E., 1953. - Acarine disease. Bee World, 34, 246-247.

Eischen F.A., J.S. Pettis and A. Dietz, 1986. - Prevention of Acarapis woodi infestation in queen honey bees with amitraz. Am. Bee J., 126, 498-500.

FekL W., 1956. - Die Bakterienflora der Tracheen und des Blutes einiger Insekten. Z. Morphol. Oekol. Tiere, 44, 442-458. 
Grordani G., 1962. - Richerche di laboratorio su Acarapis woodi Rennie agente dell' Acariosi delle api (Apis mellifera L.). Apicolt. Ital., 29, 3-11.

Giordani G., 1965. - Laboratory research on Acarapis woodi Rennie, the causative agent of acarine disease of honey bees (Apis mellifera L.) Note 2. Věd. Práce vyzkum. Ústav včelař. CSAZV4, 37-44.

Giavarinı I. and Giordani G. - Study of acarine disease of honey bee. Final Technical Rep. Instituto Nazionale di Apicoltura. 31 p. Unpublished MS.

Gomez Pajuelo P. and Fernandez Arroyo M.P., 1979. - Bee Diseases in Spain. Proc. XXVII Int. Congr. Apic. Apimondia, 341-346.

Guzman-Nova E. and A., Zozaya-Rubio C.F., 1984. - The effects of chemotherapy on the level of infestation and production of honey in colonies of honey bees with acariosis. Am. Bee J., 124, 669672.

KAESER W., 1952. - Untersuchungen zur Widerstandsfähigkeit der Innenmilbe (Acarapis woodi) der Honigbiene und zur Möglichkeit ihrer Bekämpfung. Z. Bienenforsch., 1, 191-216.

Killick C.R., 1923. - Some aspects of the pathology of acarine disease. Bee World, 4, 169-171.

Kshirsagar K.K., 1966. - A review of the work on acarine disease of honey bees. I. History and distribution. Indian Bee J., 28 (2), 79-84.

Lavie P., 1950. - Nouvelles recherches sur le traitement de l'acariose. Notes préliminaires. Rev. Fr. Apic., (52/53) 21-27.

Margolis L., Esch G.W., Holmes J.C., Kuris A.M. and Schad G.A., 1982. - The use of ecological terms in parasitology (Report of an ad hoc committee of the American Society of Parasitologists). $J$.

Parasitol., 68, 131-132.

Morgenthaler O., 1929. - Problems of acarine disease of bees. Bee World, 10, 19-24.

Morgenthaler O., 1930. - New investigations on acarine disease. Bee World, 11, 49-50.

Morgenthaler O., 1944. - Das jahreszeitliche Auftreten der Bienenseuchen. Beih. Schweiz. Bienenztg., 1, 285-336.

Morgenthaler O., 1964. - Zur Geschichte und Naturgeschichte der Bienenmilbe Acarapis. Die Bienenpflege, (4), 71-76.

Morison G.D., 1927. - Acarine disease and the muscles of Honey Bee. Nature, 120, 259-260.

Morison G.D., 1931. - Observations on the number of mites, Acarapis woodi (Rennie) found in the tracheae of the Honey-Bee. Bee World, 12, 74-76.

Morison G.D., Jeffree E.P., Murray L. and Allen M.D., 1956. - Acarine and Nosema disease of honeybees in Britain, 1925-1947. Bull. Entomol. Res., 46, 753-759.

Prell H., 1927. - Beiträge zur Kenntnis der Milbenseuche der Honigbiene. Arch. Bienenkd., 8, 241273.

RenNiE J., 1923. - Acarine disease explained. Memoir No. 6. The North of Scotland College of Agriculture, $50 \mathrm{p}$.

Rennie J., White P.B. and Harvey E.J., 1921. - "Isle of Wight disease » in hive bees. Trans. R. Soc. Edinburgh, 52, 737-779.

SChNEIDER H., 1941. - Untersuchungen über die Acarapis - Milben der Honigbiene. Die Flügel- und Hinterleibsmilbe. Mitt. Schweiz. Entomol. Ges., 18, 318-327.

SEELEy T.D., 1978. - Life history strategy of the honey bee, Apis mellifera. Oecologia, 32, 109-118. .

SEEley T.D., 1983. - The ecology of temperate and tropical honeybee societies. Am. Sci., 71, $264-272$.

Sкrobal D., 1965. - Agents qui influencent le métabolisme respiratoire chez les abeilles acariosées (Apis mellifera L.) Bull. Apic., 7 (2), 177-180.

Smirnov A.M., 1972. - [Control of acarine disease]. Pchelovodstvo, (4), 19-22. (In Russian).

Snedecor G.W. and Cochran W.G., 1967. - Statistical methods. The Iowa State University Press, Ames (Iowa), $593 \mathrm{p}$.

Whrte P.B., 1921. - The pathology of Isle of Wight Disease in hive bees. Trans. R. Soc. Edinburgh, 52, $755-764$.

WILlIE H., 1966. - Die Milbe (Acarapis woodi) in Zusammenhang mit anderen Krankheitserregern. Südwestdeutsch. Imker, 18, 322-324. 